\title{
SDC4 wt Allele
}

National Cancer Institute

\section{Source}

National Cancer Institute. SDC4 wt Allele. NCI Thesaurus. Code C101432.

Human SDC4 wild-type allele is located in the vicinity of $20 \mathrm{q} 12$ and is approximately $23 \mathrm{~kb}$ in length. This allele, which encodes syndecan-4 protein, plays a role in heparan sulfate binding. 